4

5

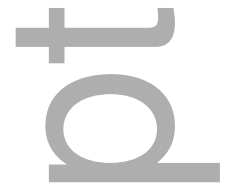

Article type : Original Manuscript

$$
\text { : Original Manuscript }
$$

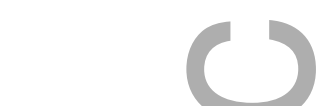

\title{
Effects of incorporating roasted lupin (Lupinus angustifolius) flour on the physicochemical and sensory attributes of beef sausage
}

${ }^{1}$ Faculty of Veterinary and Agricultural Sciences, The University of Melbourne, Parkville, VIC 3010, Australia.

* Corresponding author: Dr Zhongxiang Fang, Tel: +61 3 83445063; Email:

zhongxiang.fang@unimelb.edu.au

\section{Abstract}

The effects of incorporating lupin flour on the physicochemical and sensory characteristics of beef sausages were explored. Lupin (Lupinus angustifolius) flour was roasted, then hydrated to match the moisture content of beef meat. The beef sausage samples were manufactured for 6 treatments by replacing beef with hydrated lupin flour from 0 to $36 \%(w / w)$. Proximate analysis revealed that carbohydrate (dietary fibre) level was increased from $9.62 \%$ to $19.31 \%$, whereas fat content was decreased from $11.62 \%$ to $7.91 \%$. Inclusion of lupin flour increased the meat emulsion stability (fluid released decreased from $9.35 \%$ to $1.53 \%$ ) and decreased cooking loss from $22.70 \%$ to $14.30 \%$. Softer texture and greater adhesiveness were observed in lupin-incorporated formulations. Sensory evaluation indicated no significant difference between control and 12\% lupin enriched beef sausage formulation in appearance, aroma,

This is the author manuscript accepted for publication and has undergone full peer review but has not been through the copyediting, typesetting, pagination and proofreading process, which may lead to differences between this version and the Version of Record. Please cite this article as doi: $10.1111 / \mathrm{ijfs} .14088$

This article is protected by copyright. All rights reserved 
flavour and overall liking, suggesting lupin flour can be added to beef sausage at this level without compromising consumer acceptance.

Keywords: lupin flour, beef sausage, emulsion stability, texture profile analysis, sensory analysis.

\section{Introduction}

Recent developments in food processing have provided a great addition to the range of comminuted meat products available in the market (Marchetti et al. 2015; Sarteshnizi 2015). Nevertheless, previous research has linked these meat groups to elevated risk in 'diseases of civilization' such as coronary heart disease, cancer, and early death (Micha, Wallace \& Mozaffarian 2010). Aside from the health advices, production of ruminant meat has been associated with high greenhouse gas (GHG) emissions, a contributor of climate change (Ratnasiri \& Bandara 2017). Though the methodology of these studies remains a controversy, it has led to a shift in consumer preferences and has given rise to a new wave of innovation in the search for plant-derived meat substitutes.

Lupin is a legume that has been grown and cultivated in the Mediterranean region over the past 3000 years. The variety $L$. angustifolius has a very high protein content (33-44\%), a high non-starch polysaccharides content (around 40\%), and a relatively low lipid content (6-8\%) (Sedlakova et al. 2016). Several clinical trials and animal studies have shown the potential nutraceutical effect of lupin in lowering the risk of obesity, cardiovascular disease and diabetes (Archer et al. 2004; Bouchoucha et al. 2016; Sedlakova et al. 2016). Due to its nutritional and functional effect, lupin has been utilised in the manufacture of various food products including bread (Villarino et al. 2014), muffins (Nasar-Abbas \& Jayasena 2012), pasta (Lampart-Szczapa et al. 1997) and noodles (Jayasena, Leung \& Nasar-Abbas 2010).

However, inclusion of lupin in comminuted meat products has been met with some textural and sensory challenges. Addition of lupin protein isolates (LPIs) at 2\% was shown to significantly increase the texture parameter values (hardness, gumminess, chewiness) of comminuted meat gels (Mavrakis, Doxastakis and Kiosseoglou 2003). The only other study to incorporate lupin (Lupinus albus variety) flour into sausage was undertaken by Papavergou, Bloukas and Doxastasis (1999), who reported the pro-oxidant effect of lupin and an unacceptable rancid and bitter flavour and odour at $2 \%$. The high lipoxygenase activity in L. angustifolius $\mathrm{cv}$. Boregine flour induces the release of odorant compounds, including 
alkyl-methoxypyrazines and terpenes, that give rise to 'metallic, hay-like, grassy, cheese-like, meat-fatty like' attributes (Bader et al. 2009).

Roasting is one of the methods that has been proven to remove the off-flavours and rancidity associated with lupin flour (Yanez et al. 1986). To the best of our knowledge, no studies have shown the effects of incorporating roasted lupin (L. angustifolius) flour, with meat substitution of higher than $2 \%$, on the physicochemical and sensory properties of sausage products. Additionally, sensory analysis has never been performed on lupin-enriched sausage formulations.

By measuring physicochemical and sensory attributes, the objective of this study was to compare beef sausage quality with different ratios of meat and lupin flour. Ultimately, this study aims to contribute to the development of alternative high plant protein sausages, which addresses current health and environmental issues, without compromising consumer acceptance.

\section{Materials and Methods}

\section{Ingredients}

Fresh beef meat was obtained from a local butcher (Shing Hing Wholesale, Keon Park, VIC, Australia). Immediately after purchasing, the meat was frozen at $-20{ }^{\circ} \mathrm{C}$ in a freezer. Prior to sausage manufacturing, the meat was defrosted for 24 hours in a refrigerator at $4{ }^{\circ} \mathrm{C}$.

Lupin (L. angustifolius) flour was supplied by Irwin Valley Pty Ltd (Morawa, WA, Australia). Seasonings (containing mainly rice flour, salt, triphosphate emulsifier, spice extracts) were supplied by J. Delaney \& Co (Warriewood, NSW, Australia). Collagen sausage casing $(25 \mathrm{~mm})$ was supplied by Nippi Incorporated (Tokyo, Japan). Table 1 shows the original chemical composition of the main raw materials. Chemicals of trichloroacetic acid (TCA), sodium phosphate (dibasic and monobasic), sodium hydroxide pellets, methanol, chloroform and copper sulfate (II) pentahydrate were ordered from Bio21 Store, University of Melbourne (Parkville, VIC, Australia). 2-thiobarbituric acid (TBA) and magnesium acetate were delivered from Sigma-Aldrich Pty (Castle Hill, NSW, Australia).

\section{Sausage preparation}


Lupin flour was roasted in an oven (Westinghouse Electric Company LLC, Cranberry Township, Pennsylvania, USA) at $180{ }^{\circ} \mathrm{C}$ for $20 \mathrm{~min}$, in the process losing its entire original water content, then hydrated to $70 \%$ moisture content to match the moisture content of beef meat (Table 1). For every trial, approximately $5 \mathrm{~kg}$ of beef meat and $1 \mathrm{~kg}$ of hydrated lupin flour were refrigerated at $4{ }^{\circ} \mathrm{C}$ overnight. Together with seasonings and cold water, the mixture was chopped for eight min by a meat bowl chopper (MTK562 CBS Foodtech Pty Ltd., Warriewood, NSW, Australia) in accordance to the formulations shown in Table 2. The resulting meat batter was transferred into sausage stuffing equipment (Constante Imports, Preston, VIC, Australia), stuffed into collagen casings and twisted to form links. The sausages were left in a refrigerator $\left(4^{\circ} \mathrm{C}\right)$ for at least 24 hours to equilibrate before cooking. The physicochemical analysis and sensory evaluation were done within 3 hours after the sausages were cooked. Duplicates of the six formulation sausages were made and analysed.

\section{Emulsion stability parameters}

The emulsion stability of the formulations was evaluated by the procedure described by Horita et al. (2011) with minor modifications. Around $15 \mathrm{~g}$ of raw meat batter of each formulation were inserted in tubes and centrifuged $\left(2400 \times g, 5 \mathrm{~min}, 4{ }^{\circ} \mathrm{C}\right)$ with an Allegra X-12R centrifuge (Beckman Coulter Australia Pty Ltd, Mount Waverley, VIC, Australia). The tubes were incubated at $75^{\circ} \mathrm{C}$ for $60 \mathrm{~min}$ and left upside down at room temperature for at least $90 \mathrm{~min}$. Fluid released were determined by weighing the tubes before and after the incubation. Fat released was calculated from the difference of the fluid weight after drying in oven at $100{ }^{\circ} \mathrm{C}$ for 16 hours. The remaining fluid was regarded as the amount of water released. For every formulation, all three parameters (fluid, fat and water released) were calculated as a percentage of the original batter weight and measured in duplicate.

\section{Cooking loss}

Sausages were baked in the Westinghouse oven at $200{ }^{\circ} \mathrm{C}$ for 24 min to reach an internal temperature of $71{ }^{\circ} \mathrm{C}$, flipping once after $12 \mathrm{~min}$. After cooking, sausages were washed in cold water, dried and placed in refrigerator $\left(4^{\circ} \mathrm{C}\right)$ for analysis (Tahmasebi et al. 2016). Sausage samples were weighed before and after cooking to determine the percentage of cooking loss.

$$
\text { Cooking Loss }(\%)=\frac{\text { Weight of raw sausage }(g)-\text { weight of cooked sausage }(g)}{\text { Weight of raw sausage }(g)} \times 100
$$




\section{Proximate analysis}

The moisture, protein, fat and ash content of samples were determined based on the Association of Analytical Chemists methods (AOAC 2011). Tests were carried out in triplicate.

The amount of carbohydrate in samples was calculated based on the following equation:

$$
\text { Carbohydrate }(\%)=100-\text { moisture }(\%)-\operatorname{protein}(\%)-\operatorname{lipid}(\%)-\operatorname{ash}(\%)
$$

\section{Colour Determination}

Colour of the sausages was measured based on the CIE L* (black-white), a* (green-magenta) and b* (blue-yellow) values on a scale of 0 to 100 by Nix Pro Color Sensor (Nix Sensor Ltd., Hamilton, Ontario, Canada), in which D50 illumination and $2^{\circ}$ settings were applied in calculation of the colour scales. Raw sausages were scanned on its surface colour, whereas cooked sausages were scanned on its internal colour. Measurements were done in triplicate for each sample.

\section{Texture profile analysis (TPA)}

Textural attributes of cooked sausage were assessed using the double-bite compression procedure by the LS5 Lloyd Material Single Column Testing (Ametek Inc., Berwyn, Pennsylvania, USA). The sausages were sliced into cylinders of $15 \mathrm{~mm}$ in height and $25 \mathrm{~mm}$ in diameter, and placed at room temperature for approximately $100 \mathrm{~min}$ before each analysis (Tahmasebi et al. 2016). All samples were then compressed by a thick cylindrical probe (20 $\mathrm{mm}$ diameter) to $50 \%$ of its original height, in two successive bites of 0.1 second interval, and probe speed of $50 \mathrm{~mm} / \mathrm{min}$ at room temperature. The capacity of load cell used was 500 $\mathrm{N}(50 \mathrm{~kg})$. Measurements were done in quadruplicate for every sample. The data of hardness, adhesiveness, cohesiveness, gumminess, springiness and chewiness were obtained using the NEXYGENPlus measurement software (Ametek Inc.,Berwyn, Pennsylvania, USA).

\section{TBARS analysis}

Lipid oxidation was evaluated based on the TBARS (thiobarbituric acid reactive substances) method by Sorensen and Jorgensen (1996) with some modifications. An aliquot of $25 \mathrm{~mL}$ of $20 \%$ tricholoroacetic acid (TCA) and $20 \mathrm{~mL}$ distilled water were added into a tube containing $5 \mathrm{~g}$ of sausage sample. The mixture was homogenised using an Ika Ultra Turrax homogeniser 
least one hour. The tubes were then centrifuged at 2,000 rpm for $10 \mathrm{~min}$ at room temperature. The mixture was filtered with a Whatman No.1 filter paper and $5 \mathrm{~mL}$ of the filtrate was mixed with $5 \mathrm{~mL} 0.02 \mathrm{M}$ thiobarbituric acid (TBA), incubated in tubes at $95{ }^{\circ} \mathrm{C}$ for $20 \mathrm{~min}$ and washed with cold water. Absorbance was measured at $532 \mathrm{~nm}$ with a UV-1800 spectrophotometer (Shimadzu Corp., Kyoto, Japan) against a distilled water blank. The TBARS value was obtained from the malonaldehyde (MDA) standard curve plotted from serial dilutions of 1,1,3,3-tetramethoxypropane (TEP). Measurements were done in duplicate for each sample. All values were reported as mg MDA/ $\mathrm{kg}$ of sample.

\section{Sensory analysis}

The sensory analysis protocol has been approved by the Human Research Ethics Committee of The University of Melbourne, VIC, Australia under the ethics ID number 1750301. A total of 48 participants (Average age: 26.96 years; Age range: 18-58; Gender distribution: $39.58 \%$ Male, $54.17 \%$ Female, $6.25 \%$ prefer not say) were recruited among students and staff on campus as untrained consumer panel.

The six sausage formulations were evaluated in terms of the aroma, appearance, flavour, texture and overall acceptance on a 9-point hedonic scale (1: extremely dislike, 9: extremely like). A random three-digit code was generated for each formulation, and each participant was assigned a randomized order of which to consume the samples. Each sausage sample was served at approximately $10 \mathrm{~mm}$ in height and $25 \mathrm{~mm}$ in diameter at room temperature. Panellists were asked to consume the given water and water cracker (Woolworths Ltd., Bella Vista, NSW, Australia) between every sample to neutralize any possible interactive influence. All testing was conducted in an isolated sensory booth of standard dimensions, in room temperature and standard white light.

\section{Statistical analysis}

Data was examined using one-way ANOVA of the general linear model on Minitab 18 statistical analysis software (Minitab Inc., PA, USA). Means were grouped based on Bonferroni Pairwise Comparison for sensory analysis and the Fisher's least significant difference (LSD) test for the rest of measurements with 95\% confidence level (two-sided) (Viljoen, de Kock \& Webb 2002). 


\section{Results and Discussion}

\section{Proximate analysis}

In this study, the moisture content of lupin flour was hydrated to match that of the beef meat to prevent excessive dryness and eliminates moisture as a factor that explains any differences among formulations in terms of its physicochemical and sensory characteristics. After being subjected to cooking temperature, the moisture content in all formulations did not differ significantly $(P>0.05)$ (Table 3$)$. Despite the original protein concentration in lupin flour is about $38.1 \%$ (Table 1), the hydration of lupin to a same moisture content of meat (about $70.5 \%$ ) had diluted the lupin protein concentration. It explains the trend of diminishing protein content in formulations with higher proportion of lupin flour (Table 3). Lipid and ash contents in the sausage formulations also had the same trend to that of protein, i.e. their content was decreasing with a greater proportion of lupin flour. The carbohydrate content in all lupin-enriched formulations was higher than the control (beef only) formulation. This finding is expected as lupin flour, albeit the hydration, consists of around $40 \%$ carbohydrate, of which is mostly non-starch polysaccharides (NSP) and dietary fibre (Sedlakova et al. 2016).

Past research has suggested the protective effect of lupin fibre and protein against the risk of cardiovascular disease, hypertension and diabetes. Increased fibre intake has been linked with reduction of systolic and diastolic blood pressure in several meta-analyses (Streppel 2005). Hall et al. (2005) reported around 5\% reduction in total and LDL (low density lipoprotein) cholesterol of healthy males after supplementation of 17-30 grams lupin kernel fibre daily for one month. Though the exact mechanism is not clearly understood, Pilvi et al. (2006) suggested that arginine in lupin may induce the synthesis of nitrogen oxide, which is involved in enhancing endothelial functions and vessel relaxation. A randomized-controlled trial involving type 2 diabetes by Bouchoucha et al. (2016), demonstrated the blood pressure reducing effect of gamma-conglutin from lupin (L. albus).

\section{Emulsion stability and cooking loss}

Table 4 indicates that the hydrated lupin flour is associated with improving the stability of the meat emulsion system, where a reduction in fluid released, fat released, and water released was observed with increasing lupin content. This suggests the lupin protein may have higher emulsifying capacity than meat protein, or that the high NSP content in lupin flour may play a role in retaining fat/water. The positive emulsifying properties of lupin proteins, as well as 
other plant based proteins such as soy, have been well established in previous studies (King, Aguirre, \& De Pablo, 1985). However, fibres are also well known to improve emulsion stability (Abdul-Hamid \& Luan, 2000), and consequently both the lupin protein or the lupin fibre (or a synergy between the two), could be responsible for the increased emulsion stability observed.

Cheetham, Cheung \& Evans (1993) characterized the principal NSP structure of Lupinus angustifolius (Gungurru) cotyledons and proposed that the backbone is similar to rhamnogalacturonan with abundant short, linear galactans $(1 \rightarrow 4)-\beta-D-G a l p$ and highly branched arabinans as side chains. The greater mobility of these side chains may explain the higher water affinity (Ha et al. 2005) and therefore higher water binding capacity.

This finding is in agreement with some previous studies. Naveen et al. (2016) added up to $10 \%$ soy flour in duck meat sausages and found a trend of increasing emulsion stability with higher proportion of the extender. Similarly, the water holding capacity of beef sausages was significantly improved after the inclusion of common bean flour (Dzudie, Scher \& Hardy 2002). In a study of integrating corn germ protein flour into beef frankfurters, Hung and Zayas (1992) observed significantly $(\mathrm{P}<0.05)$ higher emulsion stability compared to control.

The present study also demonstrated a trend of higher cooking yield with a higher proportion of lupin flour in sausage formulations (Table 4). This finding could be attributed to the high emulsion stability and fat retention capacity of lupin flour. Similar results on cooking yield were recorded in past research by incorporating various plant flours into sausage formulations. Dzudie, Scher \& Hardy (2002) concluded that higher addition of common bean flour in beef sausages results in lower cooking loss. After inclusion of rice flour in emulsified pork sausages, Pereira, Zhou \& Zhang (2016) recorded a significantly $(\mathrm{P}<0.05)$ increased cooking yield as compared to control. Fang et al. (2018) added 3\% of sugarcane fibre into chicken sausage and reported significant decrease in cooking loss.

One limit of the present study should be noted is that the objective of the design was to control for moisture content, as lupin content increased there was also a decrease in fat content, which may have influenced fat percentage released. Future studies with this sausage system could look to control for fat content. 


\section{Colour determination}

261

262

263

264

265

266

267

268

269

270

271

272

273

274

275

276

277

278

279

280

281

282

283

284

285

286

287

288

289

290

291

292

293

Table 5 suggests that there is some variability in the extent of lightness ( $\mathrm{L}^{*}$ values) and redness ( $\mathrm{a}^{*}$ values) for the raw sausages, which may be attributed to uneven browning and mixing of lupin flour during the roasting process. Results demonstrated a significant $(\mathrm{P}<0.05)$ difference in yellowness between control and the rest of lupin-incorporated formulations, which is expected from the higher $b^{*}$ values of roasted lupin flour and seasoning (Table 5). This supports the finding by Mansour and Khalil (1999) that the yellowness values were higher after incorporating wheat fibres into uncooked beef burgers. Nonetheless, the current findings are contradictory to Papavergou, Bloukas and Doxastakis (1999) who recorded no significant $(P<0.05)$ effect of lupin protein isolate and lupin flour on the $L^{*}, a^{*}, b^{*}$ values of fermented sausages. The reason may be due to the low percentage $(2 \%)$ of incorporated lupin, as compared to at least $12 \%$ of the total ingredient composed of lupin in this study (Table 2). Additionally, after being subjected to the roasting process, the lupin flour had a more yellowish colour (Table 5).

A higher proportion of roasted lupin flour is associated with the trend of decreasing $L^{*}$ values, and increasing both $a^{*}$ and $b^{*}$ values in cooked beef sausage (Table 5). This result is in agreement with some studies that recorded lower lightness but higher redness values with higher substitution of minced beef meat with plant flours (Brown \& Zayas 1990; Dzudie, Scher \& Hardy 2002). Besides the denaturation of myoglobin in meat, lupin flour and seasoning (contains mainly rice flour) was subjected to conditions similar to the roasting process, thence the occurrence of Maillard browning reaction. The combined effects may have intensified the darker colour in the sausage formulations. Additionally, rather than the colour of the added flour, the higher redness and yellowness values in lupin-enriched formulations may be attributed more from the dilution of the brown meat pigment ferrihemochrome (Tabarestani \& Tehrani 2014).

\section{Texture profile analysis (TPA)}

The TPA of sausage is shown in Table 6, which indicates that higher substitution by hydrated lupin flour is associated with lower hardness, cohesiveness, gumminess, springiness and chewiness. This result parallels the trend found by Kerr, Wang and Choi (2005) who reported the softer texture in Italian pork sausages incorporated with up to $30 \%$ hydrated oat. In a study that focused on the manufacture of low-fat sausages, Yang et al. (2007) also showed significantly $(\mathrm{P}<0.05)$ lower hardness, cohesiveness and gumminess after inclusion of 10- 
$25 \%$ hydrated oatmeal and tofu. When exposed to cooking temperature, the myofibrillar and sarcoplasmic proteins in muscle tissue unfold, entangle with each other to form a solid protein gel matrix. This process is also known as gelation and explains the harder texture of the cooked sausages (Table 6).

Lupin flour seems to have the opposite character to meat in an emulsion system. Raikos et al. (2014) recorded that lupin flour has a relatively poor gelling capacity compared to other plant foods (wheat, buckwheat, green pea). They suggested that lupin's low level of non-fibre carbohydrates, leads to weaker intermolecular forces and reduced cohesiveness. Troutt et al. (1992) theorized that the high water binding capacity of meat extenders may explain the decrease in the firmness of sausage. Nevertheless, as Table 3 shows that even after cooking, no significant $(P>0.05)$ difference was found in the moisture content of all formulations. Thus, it is likely that the softer texture is due to the weak internal structure of lupin flour, lower protein content in lupin-enriched formulations, or disruption of protein matrix by its components (non-meat proteins, carbohydrates), rather than the meat extender's capacity to retain moisture (Kerr, Wang \& Choi 2005). However, the exact effect of legume-based extenders in a meat emulsion system, including its relation to moisture retention, still remain a subject of debate.

Additionally, there was a trend of increasing adhesiveness (stickiness) with higher content of hydrated lupin flour. Similar results were obtained by Jayasena, Leung and Nasar-Abbas (2010) who substituted up to $50 \%$ of wheat flour with lupin flour in instant noodles. This could be attributed to the moisture binding capacity of non-starch polysaccharides and dietary fibre in lupin. In the food industry, excessive stickiness is undesirable as it increases the risk of damage to machinery (Agrahar-Murugkar et al. 2015).

\section{TBARS analysis}

Results indicate that substitution of meat with lupin flour may promote lipid oxidation, as shown by the significant $(P<0.05)$ difference between control and all cooked lupin-enriched formulations (Table 7). Lupin seeds have a very high proportion (80\%) of unsaturated fatty acids (Yanez et al. 1983). The presence of double bonds in unsaturated fats decreases the bond dissociation energy of the neighbouring carbon-hydrogen bonds, thus increasing its susceptibility to extraction of hydrogen atoms and conversion to lipid radical. Papavergou, Bloukas and Doxastakis (1999) described the lupin (L. albus) seed flour as having a 'pro- 
oxidant' effect, a term used for substances that accelerate oxidative stress or limit antioxidant capacity. This claim was based on the finding that lupin flour-treated sausage scored the highest TBARS value among all formulations, including control.

Although the addition of lupin flour is linked to higher lipid oxidation, all TBARS values presented in this study (Table 7) is far below the human detectable threshold level of $0.6 \mathrm{mg}$ MDA $/ \mathrm{kg}$ (Sheard et al. 2000), thus the off-flavours and rancidity of the sausages are unlikely to be detected by consumers.

\section{Sensory analysis}

Sensory analysis indicated that there was no significant $(\mathrm{P}<0.05)$ effect of lupin flour on the appearance seores of the sausages, even when the lupin flour was added to $36 \%$ (Table 8). This is in agreement with the only known study to have evaluated the sensory properties of lupin-incorporated sausages by Papavergou, Bloukas and Doxastakis (1999), although their incorporation level was much lower (2\%).

Additionally, similar results were reported for aroma across all sausage formulations (Table 8). Insignificant $(P>0.05)$ differences were also exhibited between the flavour scores for control and formulations with up to $18 \%$ lupin content. The present observation disagrees with the study by Papavergou, Bloukas and Doxastakis (1999) who reported unacceptably lower flavour and odour scores for fermented sausages with $2 \%$ lupin flour. This provides the evidence that oven roasting at $180{ }^{\circ} \mathrm{C}$ for $20 \mathrm{~min}$ in this study may restrict lipoxygenase activity and remove much of the 'beany' odour, bitter and rancid flavour associated with lupin flour. Furthermore, it confirms the pre-heating method to improve the legume flavour, as proposed by Yanez et al. (1987). Nevertheless, when more than $18 \%$ of meat was substituted with roasted lupin, there was a steep decline in the flavour scores, suggesting that the removal of lupin off-flavours was not complete by the roasting process, and/or the consumers generally prefer meat flavour to that of lupin flavour.

The sensory data also indicated that inclusion of hydrated lupin flour is associated with poor textural properties, with none of the lupin-containing formulations regarded in the statistically $(P<0.05)$ same group as control (Table 8$)$. It mimics the trend of hardness values displayed from the textural profile analysis in Section 3.4 and Table 6. This may support the argument by Caine et al. (2003) who suggested that hardness was the most important TPA 
measurement explaining 31-46\% variation in sensory properties of beef steaks such as overall tenderness, overall palatability and connective tissue.

Finally, incorporation of up to $12 \%$ lupin flour resulted in overall liking scores that were not significantly $(P>0.05)$ different from control (Table 8). Two other lupin-containing formulations (lupin level up to 24\%) also displayed mean overall liking scores above five (neither like nor dislike). This appears to be the first study to confirm the potential consumer acceptability of roasted lupin flour in beef sausages. However, as observed with flavour and texture, a steady decline in overall acceptability is seen with increasing lupin content. This suggests that texture and flavour are the two most important sensory modalities driving the differences between formulations for overall liking, and thus should be the focus areas for improvement in future studies with processed meat products containing lupin.

\section{Conclusion}

Meat substitution of lupin flour within beef sausage (from $0 \%$ up to $36 \%$ of total ingredient composition) increased carbohydrate levels, decreased fat content, and decreased protein content (a constant moisture content was maintained). Increasing lupin flour also improved emulsion stability and cooking yield. However, as lupin content increased the strength of the textural structure became weaker (texture profile analysis parameters declined: hardness, cohesiveness, gumminess, springiness and chewiness). Sensory analysis revealed that lupin flour could be incorporated in the manufacture of beef sausages up to a level of $12 \%$ of the total ingredient composition without significantly affecting consumer acceptability. Substituting lupin flour at higher levels (up to 36\%) had a negative impact on consumer acceptability in terms of flavour and texture. Consequently, further research is required to improve the texture attributes and reduce the "beany" flavour of the sausage, when lupin is added as a plant protein and dietary fibre source.

\section{Conflicts of interest}

None

\section{References}


Abdul-Hamid, A., \& Luan, Y. S. (2000). Functional properties of dietary fibre prepared from defatted rice bran. Food Chemistry, 68, 15-19.

Agrahar-Murugkar, D., Gulati, P., Kotwaliwale, N. \& Gupta, C. (2015). Evaluation of nutritional, textural and particle size characteristics of dough and biscuits made from composite flours containing sprouted and malted ingredients. Journal of Food Science and Technology, 52, 5129-5137.

Archer, B.J., Johnson, S.K., Devereux, H.M. \& Barter, A.L. (2004). Effect of fat replacement by inulin or lupin-kernel fibre on sausage patty acceptability, post-meal perceptions of satiety and food intake in men. British Journal of Nutrition, 91, 591-599.

Association of Official Analytical Chemists (AOAC). (2011), Official methods of analysis (18 ${ }^{\text {th }}$ Edition), Washington, DC.

Bader, S., Czerny, M., Eisner, P. \& Buettner, A. (2009). Characterisation of odour-active compounds in lupin flour. Journal of the Science of Food and Agriculture, 89, 2343-2518.

Bouchoucha, R., Fradj, M.K.B., Bouchoucha, M., Akrout, M., Feki, M., Kaabachi, N., Raies, A. \& Slimane, H. (2016). Anti-hyperglycaemic and anti-hyperlipidemic effects of lupines albus in type 2 diabetic patients: a randomized double-blind, placebo-controlled clinical trial. International Journal of Pharmacology, 12, 830-837.

Caine, W.R., Aalhus, J.L., Best, D.R., Dugan, M.E.R. \& Jeremiah, L.E. (2003). Relationship of texture profile analysis and Warner-Bratzler shear force with sensory characteristics of beef rib steaks. Meat Science, 64, 333-339.

Cheetam, N.W.H., Cheung, P.C.K. \& Evans, A.J. (1993). Structure of the principal nonstarch polysaccharide from the cotyledons of Lupinus angustifolius (cultivar Gungurru). Carbohydrate Polymers, 22, 37-47.

Dzudie, T., Scher, J. \& Hardy, J. (2002). Common bean flour as an extender in beef sausages. Journal of Food Engineering, 52, 143-147. 
Fang, Z., Lin, P., Ha, M., Warner, R.D. (2018). Effects of incorporation of sugarcane fibre on the physicochemical and sensory properties of chicken sausage. International Journal of Food Science and Technology, doi:10.1111/ijfs.13894.

431

Ha, M.A., Vietor, R.J., Jardine, G.D., Apperley, D.C. \& Jarvis, M.C. (2005). Conformation and mobility of the arabinan and galactan side-chains of pectin. Phytochemistry, 55, 18171824.

Hall, R.S., Johnson, S.K., Baxter, A.L. \& Ball, M.J. (2005). Lupin kernel fibre-enriched foods beneficially modify serum lipids in men. European Journal of Clinical Nutrition, 59, 325-333.

Horita, C.N., Morgano, M.A., Celeghini, R.M.S. \& Pollonio, M.A.R. (2011). Physicochemical and sensory properties of reduced-fat mortadella prepared with blends of calcium, magnesium and potassium chloride as partial substitutes for sodium chloride. Meat Science, $89,426-433$.

Hung, S.C. \& Zayas, J.F. (1992). Functionality of milk proteins and corn germ protein flour in comminuted meat products. Journal of Food Quality, 15, 139-152.

Jayasena, V., Leung, P.P.Y. \& Nasar-Abbas, S.M. (2010). Effect of lupin flour substitution on the quality and sensory acceptability of instant noodles. Journal of Food

Quality, 33, 709-727.

451

Kerr, W.L., Wang, X. \& Choi, S.G. (2005). Physical and sensory characteristics of low-fat 453 Italian sausâge prepared with hydrated oat. Journal of Food Quality, 28, 62-77.

King, J., Aguirre, C., \& De Pablo, S. (1985). Functional properties of lupin protein isolates

(Lupinus albus cv Multolupa). Journal of Food Science, 50, 82-87.

Lampart-Szczapa, E., Obuchowski, W., Czaczyk, K., Pastuszewska, B. \& Buraczewska, L. 459 (1997). Effect of lupine flour on the quality and oligosaccharides of pasta and crisps. 460 Nahrung, 41, 219-223. 
Mansour, E.H. \& Khalil, A.H. (1997). Characteristics of low-fat beefburger as influenced by various types of wheat fibers. Food Research International, 30, 199-205.

464

Marchetti, L., Argel, N., Andres, S.C. \& Califano, A.N. (2015). Sodium-reduced lean sausages with fish oil optimized by a mixture design approach. Meat Science, 104, 67-77.

Mavrakis, C., Doxastakis, G. \& Kiosseoglou, V. (2003). Large deformation properties of gels and model comminuted meat products containing lupin protein. Journal of Food Science, 68, 1371-1376

Micha, R., Wallace, S.K. \& Mozaffarian, D. (2010). Red and processed meat consumption and risk of incident coronary heart disease, stroke, and diabetes mellitus: a systematic review and meta-analysis. Circulation, 121, 2271-2283.

Nasar-Abbas, S.M. \& Jayasena, V. (2012). Effect of lupin flour incorporation on the physical and sensory properties of muffins. Quality Assurance and Safety of Crops and Foods, 4, 4149.

Papavergou, E.J., Bloukas, J.G. \& Doxastakis, G. (1999). Effect of lupin seed proteins on quality characteristics of fermented sausages. Meat Science, 52, 421-427.

Pilvi, T.K., Jauhiainen, T., Cheby, Z.J., Mervaala, E.M., Vapaatalo, H. \& Korpela, R. (2006). Lupin protein attenuates the development of hypertension and normalises the vascular function of NaCl-loaded Goto-Kakizaki rats. Journal of Physiology and Pharmacology, 57, 167-176. 
Raikos, V., Neacsu, M., Russell, W. \& Duthie, G. (2014). Comparative study of the functional properties of lupin, green pea, fava bean, hemp, and buckwheat flours as affected by pH. Food Science and Nutrition, 2, 802-810.

Ratnasiri, S. \& Bandara, J. (2017). Changing patterns of meat consumption and greenhouse gas emissions in Australia: Will kangaroo meat make a difference? PLos ONE, 12, 1-13.

Sarteshnizi, R.A., Hosseini, H., Bondarianzadeh, D., Colmenero, F.J. \& Khaksar, R. (2015). Optimization of prebiotic sausage formulation: Effect of using $\beta$-glucan and resistant starch by D-optimal mixture design approach. LWT - Food Science and Technology, 62, 704-710.

Sedlakova, K., Strakova, E., Suchy, P., Krejcarova, J. \& Herzig, I. (2016). Lupin as a perspective protein plant for animal and human nutrition - a review. Acta Veterinaria Brno, $85,165-175$.

Sheard, P.R., Enser, M., Wood, J.D., Nute, G.R., Gill, B.P. \& Richardson, R.I. (2000). Shelf life and quality of pork and pork products with raised n-3 PUFA. Meat Science, 55, 213-221.

Sorensen, G. \& Jorgensen, S.S. (1996). A critical examination of some experimental variables in the 2 . thiobarbituric acid (TBA) test for lipid oxidation in meat products. Zeitschrift für Lebensmitteluntersuchung und-Forschung A, 202, 205-210.

Streppel, M.T., Arends, L.R., Grobbee, D.E., Veer P. \& Gelejinse, J.M. (2005). Dietary fiber and blood pressure: a meta-analysis of randomizedplacebo-controlled trials. Archives of Internal Medicine, 165, 150-156.

Tabarestani, H.S. \& Tehrani, M.M. (2014). Optimization of physicochemical properties of low-fat hamburger formulation using blend of soy flour, split pea flour and wheat starch as part of fat replacer system. Journal of Food Processing and Preservation, 38, 278-288.

Tahmasebi, M., Labbafi, M., Emam-Djomeh, Z. \& Yarmand, M.S. (2016). Manufacturing the novel sausages with reduced quantity of meat and fat: The product development, formulation optimization, emulsion stability and textural characterization. LWT - Food Science and Technology, 68, 76-84. 
530 Troutt, E.S., Hunt, M.C., Johnson, D.E., Claus, J.R., Kastner, C.L. \& Kropf, D.H. (1992).

531 Characteristics of low-fat ground beef containing texture-modifying ingredients. Journal of 532 Food Science, 57, 19-24.

533

534

535

536

537

538

539

540

541

542

543

544

545

546

547

548

549

550

551

Viljoen, H.F., de Kock, H.L. \& Webb, E.C. (2002). Consumer acceptability of dark, firm and dry (DFD) and normal pH beef steaks. Meat Science, 61, 181-185.

Villarino, C.B., Jayasena, V., Coorey, R., Chakrabarti-Bell, S. \& Johnson, S. (2014). The effects of bread-making process factors on Australian sweet lupin-wheat bread quality characteristies. International Journal of Food Science and Technology, 49, 2373-2381.

Yanez, E., Ivanovic, D., Owen, D.F. \& Ballester, D. (1983). Chemical and nutritionalevaluation of sweet lupins. Annals of Nutrition and Metabolism, 27, 513-520.

Yanez, E., Lobos, P., Diaz, G. \& Bellester, D. (1986). Effect of roasting on the chemical composition and protein quality of lupin seeds (Lupinus albus cv. Multolupa). Journal of Food Science, 51, 1235-1238.

Yang, H.S., Choi, S.G., Jeon, J.T., Park, G.B. \& Joo, S.T. (2007). Textural and sensory properties of low fat pork sausages with added hydrated oatmeal and tofu as texturemodifying agents. Meat Science, 75, 283-289.

Table 1. Chemical composition (in $\mathrm{g} / 100 \mathrm{~g}$ ) of raw materials

\begin{tabular}{cccccc}
\hline $\begin{array}{c}\text { Raw } \\
\text { Materials }\end{array}$ & Moisture & Protein & Lipid & Ash & Carbohydrate \\
\hline Beef meat & $70.46 \pm 1.57$ & $21.61 \pm 3.86$ & $16.99 \pm 3.30$ & $1.93 \pm 0.36$ & - \\
Lupin flour & $7.86 \pm 1.31$ & $38.1 \pm 5.3$ & $7.47 \pm 0.18$ & $3.15 \pm 0.16$ & $38.5-43^{a}$
\end{tabular}

552

${ }^{a}$ Total carbohydrate content as shown in the product technical data sheet.

553 Table 2. Six different sausage formulations with variable proportion of beef and lupin flour 554 (wet weight)

\begin{tabular}{ccccc}
\hline Formulation & Beef Meat (\%) & Lupin Flour (\%) & Seasonings (\%) & Water (\%) \\
& & & \\
\hline L36 & 36 & 36 & \\
L30 & 42 & 30 & \\
\hline
\end{tabular}




\begin{tabular}{ccccc}
\hline L24 & 48 & 24 & 8 & 20 \\
L18 & 54 & 18 & & \\
L12 & 60 & 12 & & \\
C & 72 & 0 & & \\
\hline
\end{tabular}

555

556 Table 3. Proximate values of cooked beef sausage formulations enriched with hydrated lupin

557 flour

\begin{tabular}{lccccc}
\hline Formulation & Moisture (\%) & Protein (\%) & Fat $(\%)$ & Ash (\%) & $\begin{array}{c}\text { Carbohydrate } \\
(\%)\end{array}$ \\
\hline L36 & $60.44 \pm 1.56^{\mathrm{a}}$ & $10.17 \pm 0.47^{\mathrm{a}}$ & $7.91 \pm 1.73^{\mathrm{a}}$ & $1.70 \pm 0.04^{\mathrm{a}}$ & $19.31 \pm 0.54^{\mathrm{a}}$ \\
L30 & $60.37 \pm 0.97^{\mathrm{a}}$ & $9.95 \pm 0.25^{\mathrm{a}}$ & $9.04 \pm 0.18^{\mathrm{ab}}$ & $1.77 \pm 0.04^{\mathrm{ab}}$ & $18.62 \pm 0.88^{\mathrm{a}}$ \\
L24 & $60.87 \pm 1.34^{\mathrm{a}}$ & $11.94 \pm 1.79^{\mathrm{ab}}$ & $9.29 \pm 0.17^{\mathrm{ab}}$ & $1.84 \pm 0.06^{\mathrm{b}}$ & $15.88 \pm 1.52^{\mathrm{a}}$ \\
L18 & $60.05 \pm 0.33^{\mathrm{a}}$ & $11.70 \pm 3.28^{\mathrm{ab}}$ & $9.79 \pm 0.50^{\mathrm{bc}}$ & $1.89 \pm 0.06^{\mathrm{b}}$ & $16.57 \pm 3.42^{\mathrm{ab}}$ \\
L12 & $61.15 \pm 4.34^{\mathrm{a}}$ & $14.57 \pm 4.11^{\mathrm{bc}}$ & $10.07 \pm 0.21^{\mathrm{bc}}$ & $1.96 \pm 0.05^{\mathrm{bc}}$ & $12.26 \pm 4.43^{\mathrm{bc}}$ \\
C & $61.38 \pm 2.18^{\mathrm{a}}$ & $15.37 \pm 0.58^{\mathrm{c}}$ & $11.62 \pm 0.13^{\mathrm{c}}$ & $2.02 \pm 0.27^{\mathrm{bc}}$ & $9.62 \pm 2.13^{\mathrm{c}}$ \\
\hline
\end{tabular}

558 Means sharing the same letter ${ }^{\mathrm{a}, \mathrm{b}, \mathrm{c}}$ in the same column is not significantly $(P<0.05)$ different 559 from each other (Fisher's LSD Test).

560 Table 4. Emulsion stability and cooking loss percentage for the six sausage formulations

\begin{tabular}{lll}
\hline Formulation & Emulsion stability parameters & Cooking loss
\end{tabular}

$$
\text { Fluid released } \quad \text { Fat released }(\%) \text { Water released }(\%)
$$

\begin{tabular}{lllll}
\hline L36 & $1.53 \pm 0.29^{\mathrm{a}}$ & $1.47 \pm 0.29^{\mathrm{a}}$ & $0.06 \pm 0.09^{\mathrm{a}}$ & $14.30 \pm 1.04^{\mathrm{a}}$ \\
L30 & $2.27 \pm 0.33^{\mathrm{ab}}$ & $2.16 \pm 0.30^{\mathrm{ab}}$ & $0.11 \pm 0.05^{\mathrm{a}}$ & $14.92 \pm 1.73^{\mathrm{a}}$ \\
L24 & $2.92 \pm 0.23^{\mathrm{bc}}$ & $2.67 \pm 0.20^{\mathrm{bc}}$ & $0.25 \pm 0.03^{\mathrm{b}}$ & $16.29 \pm 2.18^{\mathrm{ab}}$ \\
L18 & $3.83 \pm 0.25^{\mathrm{cd}}$ & $3.54 \pm 0.27^{\mathrm{cd}}$ & $0.30 \pm 0.02^{\mathrm{b}}$ & $16.60 \pm 1.57^{\mathrm{ab}}$ \\
L12 & $4.37 \pm 0.02^{\mathrm{d}}$ & $3.71 \pm 0.11^{\mathrm{d}}$ & $0.66 \pm 0.12^{\mathrm{c}}$ & $18.33 \pm 0.03^{\mathrm{b}}$ \\
C & $9.35 \pm 1.36^{\mathrm{e}}$ & $8.56 \pm 1.32^{\mathrm{e}}$ & $0.80 \pm 0.04^{\mathrm{d}}$ & $22.70 \pm 0.90^{\mathrm{c}}$ \\
\hline
\end{tabular}

561 Means sharing the same letter ${ }^{\mathrm{a}, \mathrm{b}, \mathrm{c}, \mathrm{d}, \mathrm{e}}$ in the same column is not significantly $(P<0.05)$

562 different from each other (Fisher's LSD Test).

563 Table 5. Colour $\left(\mathrm{L}^{*}, \mathrm{a}^{*}, \mathrm{~b}^{*}\right)$ values of raw materials, raw and cooked sausage formulations

\begin{tabular}{llll}
\hline & $L^{*}$ & $a^{*}$ & $b^{*}$ \\
\hline Lupin Flour & $36.12 \pm 3.17$ & $16.40 \pm 2.72$ & $9.76 \pm 1.27$ \\
Hydrated + Roasted & $97.27 \pm 0.90$ & $0.87 \pm 0.25$ & $32.20 \pm 1.91$
\end{tabular}

Lupin Flour

This article is protected by copyright. All rights reserved 

Seasonings
$41.35 \pm 1.68$
$15.80 \pm 1.45$
$32.28 \pm 1.37$

Raw Sausage

$\begin{array}{llll}\text { L36 } & 56.53 \pm 0.97^{\mathrm{b}} & 15.27 \pm 0.40^{\mathrm{bc}} & 26.00 \pm 0.72^{\mathrm{ab}} \\ \text { L30 } & 54.00 \pm 2.82^{\mathrm{c}} & 14.77 \pm 0.15^{\mathrm{c}} & 24.50 \pm 0.53^{\mathrm{b}} \\ \text { L24 } & 59.00 \pm 1.04^{\mathrm{a}} & 17.07 \pm 1.21^{\mathrm{a}} & 26.23 \pm 1.94^{\mathrm{a}} \\ \text { L18 } & 59.23 \pm 0.57^{\mathrm{a}} & 16.80 \pm 0.80^{\mathrm{ab}} & 26.07 \pm 0.38^{\mathrm{ab}} \\ \text { L12 } & 55.37 \pm 0.15^{\mathrm{bc}} & 14.10 \pm 0.89^{\mathrm{c}} & 22.03 \pm 0.50^{\mathrm{c}} \\ \text { C } & 54.80 \pm 0.66^{\mathrm{bc}} & 16.77 \pm 1.51^{\mathrm{ab}} & 17.03 \pm 0.55^{\mathrm{d}}\end{array}$

\section{Cooked Sausage}
L36
$45.17 \pm 3.25^{\mathrm{a}}$
$11.30 \pm 0.56^{\mathrm{ab}}$
$21.90 \pm 0.30^{\mathrm{b}}$
L30
$46.17 \pm 0.85^{\mathrm{a}}$
$12.07 \pm 0.23^{\mathrm{a}}$
$21.47 \pm 0.97^{\mathrm{b}}$
L24
$52.67 \pm 1.29^{\mathrm{b}}$
$11.13 \pm 0.64^{\mathrm{b}}$
$23.40 \pm 0.46^{\mathrm{a}}$
L18
$52.10 \pm 0.66^{\mathrm{b}}$
$10.80 \pm 0.20^{\mathrm{b}}$
$21.20 \pm 0.27^{\mathrm{b}}$
L12
$52.70 \pm 1.67^{\mathrm{b}}$
$10.80 \pm 0.10^{b}$
$19.57 \pm 0.40^{\mathrm{c}}$
C
$53.17 \pm 1.21^{\mathrm{b}}$
$9.67 \pm 0.61^{\mathrm{c}}$
$15.00 \pm 0.36^{\mathrm{d}}$

564 Means sharing the same lowercase letters ${ }^{\mathrm{a}, \mathrm{b}, \mathrm{c}, \mathrm{d}}$ in the same column are not significantly

$565(P<0.05)$ different from each other (Fisher's LSD Test), and only raw and cooked sausages

566 are compared.

567 Table 6. Textural parameters of the cooked sausage formulations

\begin{tabular}{lcccccc}
\hline F & Hardness $(\mathrm{N})$ & $\begin{array}{c}\text { Adhesiveness } \\
(\mathrm{Nmm})\end{array}$ & $\begin{array}{c}\text { Cohesiveness } \\
\text { ratio }\end{array}$ & $\begin{array}{c}\text { Gumminess } \\
(\mathrm{N})\end{array}$ & $\begin{array}{c}\text { Springiness } \\
(\mathrm{mm})\end{array}$ & Chewiness $(\mathrm{N})$ \\
\hline L36 & $15.35 \pm 1.07^{\mathrm{a}}$ & $1.336 \pm 0.860^{\mathrm{a}}$ & $0.139 \pm 0.046^{\mathrm{a}}$ & $2.14 \pm 0.74^{\mathrm{a}}$ & $0.580 \pm 0.155^{\mathrm{a}}$ & $1.29 \pm 0.71^{\mathrm{a}}$ \\
$\mathrm{L} 30$ & $17.47 \pm 2.86^{\mathrm{ab}}$ & $1.072 \pm 0.214^{\mathrm{ab}}$ & $0.129 \pm 0.029^{\mathrm{a}}$ & $2.30 \pm 0.81^{\mathrm{a}}$ & $0.640 \pm 0.276^{\mathrm{ab}}$ & $1.63 \pm 0.98^{\mathrm{a}}$ \\
$\mathrm{L} 24$ & $17.53 \pm 0.85^{\mathrm{ab}}$ & $1.181 \pm 0.270^{\mathrm{ab}}$ & $0.132 \pm 0.042^{\mathrm{a}}$ & $2.34 \pm 0.85^{\mathrm{a}}$ & $0.663 \pm 0.195^{\mathrm{ab}}$ & $1.52 \pm 0.54^{\mathrm{a}}$ \\
L18 & $19.87 \pm 0.26^{\mathrm{bc}}$ & $0.635 \pm 0.427^{\mathrm{ab}}$ & $0.288 \pm 0.163^{\mathrm{b}}$ & $5.72 \pm 3.27^{\mathrm{bc}}$ & $1.274 \pm 0.146^{\mathrm{c}}$ & $7.25 \pm 4.03^{\mathrm{b}}$ \\
L12 & $20.93 \pm 2.67^{\mathrm{c}}$ & $0.709 \pm 0.262^{\mathrm{b}}$ & $0.188 \pm 0.044^{\mathrm{ab}}$ & $4.02 \pm 1.35^{\mathrm{ab}}$ & $0.647 \pm 0.472^{\mathrm{ab}}$ & $2.15 \pm 0.65^{\mathrm{a}}$ \\
$\mathrm{C}$ & $35.22 \pm 2.14^{\mathrm{d}}$ & $0.527 \pm 0.381^{\mathrm{b}}$ & $0.225 \pm 0.099^{\mathrm{ab}}$ & $7.97 \pm 3.64^{\mathrm{c}}$ & $1.000 \pm 0.188^{\mathrm{bc}}$ & $8.30 \pm 4.77^{\mathrm{b}}$ \\
\hline
\end{tabular}

568 Means sharing the same lowercase letters ${ }^{\mathrm{a}, \mathrm{b}, \mathrm{c}, \mathrm{d}}$ in the same column are not significantly

$569(P<0.05)$ different from each other (Fisher's LSD Test).

570 Table 7. TBARS value (mg MDA/ kg) for raw and cooked sausage formulations

Formulation Raw Sausage Cooked Sausage




\begin{tabular}{lll}
\hline L36 & $0.092 \pm 0.019^{\mathrm{a}}$ & $0.203 \pm 0.121^{\mathrm{a}}$ \\
L30 & $0.089 \pm 0.070^{\mathrm{a}}$ & $0.182 \pm 0.022^{\mathrm{a}}$ \\
L24 & $0.062 \pm 0.029^{\mathrm{ab}}$ & $0.115 \pm 0.021^{\mathrm{ab}}$ \\
L18 & $0.082 \pm 0.041^{\mathrm{a}}$ & $0.118 \pm 0.029^{\mathrm{ab}}$ \\
L12 & $0.056 \pm 0.011^{\mathrm{ab}}$ & $0.069 \pm 0.024^{\mathrm{bc}}$ \\
C & $0.001 \pm 0.000^{\mathrm{b}}$ & $0.001 \pm 0.000^{\mathrm{c}}$
\end{tabular}

571 Means sharing the same lowercase letters ${ }^{\mathrm{a}, \mathrm{b}, \mathrm{c}}$ in the same column are not significantly

$572 \quad(P<0.05)$ different from each other (Fisher's LSD Test).

573 Table 8. Sensory properties of beef sausage formulations fortified with hydrated lupin flour

\begin{tabular}{lccccc}
\hline F & $\begin{array}{c}\text { Appearance } \\
\text { Liking }\end{array}$ & $\begin{array}{c}\text { Aroma } \\
\text { Liking }\end{array}$ & $\begin{array}{c}\text { Flavour } \\
\text { Liking }\end{array}$ & $\begin{array}{c}\text { Texture } \\
\text { Liking }\end{array}$ & Overall Liking \\
\hline L36 & $4.75 \pm 1.62^{\mathrm{a}}$ & $5.29 \pm 1.47^{\mathrm{a}}$ & $4.60 \pm 1.67^{\mathrm{a}}$ & $3.25 \pm 1.19^{\mathrm{a}}$ & $3.98 \pm 1.33^{\mathrm{a}}$ \\
L30 & $5.10 \pm 1.36^{\mathrm{a}}$ & $5.69 \pm 1.36^{\mathrm{a}}$ & $5.13 \pm 1.77^{\mathrm{ab}}$ & $4.21 \pm 1.61^{\mathrm{b}}$ & $4.81 \pm 1.61^{\mathrm{b}}$ \\
L24 & $5.08 \pm 1.11^{\mathrm{a}}$ & $5.44 \pm 1.25^{\mathrm{a}}$ & $5.42 \pm 1.38^{\mathrm{bc}}$ & $4.58 \pm 1.37^{\mathrm{b}}$ & $5.06 \pm 1.51^{\mathrm{bc}}$ \\
L18 & $5.35 \pm 1.14^{\mathrm{a}}$ & $5.71 \pm 1.15^{\mathrm{a}}$ & $5.96 \pm 1.17^{\mathrm{cd}}$ & $5.40 \pm 1.46^{\mathrm{c}}$ & $5.65 \pm 1.44^{\mathrm{cd}}$ \\
L12 & $5.31 \pm 1.56^{\mathrm{a}}$ & $5.94 \pm 1.31^{\mathrm{a}}$ & $6.17 \pm 1.26^{\mathrm{d}}$ & $5.52 \pm 1.60^{\mathrm{c}}$ & $5.88 \pm 1.36^{\mathrm{de}}$ \\
C & $5.42 \pm 1.65^{\mathrm{a}}$ & $5.81 \pm 1.59^{\mathrm{a}}$ & $6.42 \pm 1.54^{\mathrm{d}}$ & $6.19 \pm 1.70^{\mathrm{d}}$ & $6.48 \pm 1.37^{\mathrm{e}}$
\end{tabular}

$574 \pm$ represents the standard deviation $(\mathrm{n}=48)$. Means sharing the same lowercase letters ${ }^{\mathrm{a}, \mathrm{b}, \mathrm{c}, \mathrm{d}, \mathrm{e}}$ in

575 the same column are not significantly $(P<0.05)$ different from each other (Bonferroni

576 Pairwise Comparison).

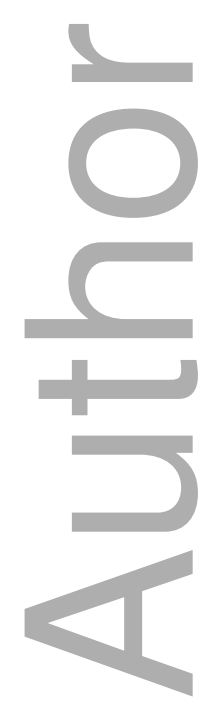

This article is protected by copyright. All rights reserved 


\section{University Library}

\section{- M M N E R VA A gateway to Melbourne's research publications}

Minerva Access is the Institutional Repository of The University of Melbourne

Author/s:

Fang, Z;Leonard, W;Hutchings, S;Warner, R

Title:

Effects of incorporating roasted lupin (Lupinus angustifolius) flour on the physicochemical and sensory attributes of beef sausage

Date:

2019-01-04

Citation:

Fang, Z., Leonard, W., Hutchings, S. \& Warner, R. (2019). Effects of incorporating roasted lupin (Lupinus angustifolius) flour on the physicochemical and sensory attributes of beef sausage. International Journal of Food Science and Technology, 54 (5), pp.1849-1857. https://doi.org/10.1111/ijfs. 14088.

Persistent Link:

http://hdl.handle.net/11343/285246 